\title{
Application of IDEF0 functional modeling methodology at the initial stage of design the modernization of TPP in ETC
}

\author{
Natalia Fedorova, ${ }^{1, *}$, Yuriy Shcheglov ${ }^{1}$, and Pavel Kobylyackiy ${ }^{2}$ \\ ${ }^{1}$ Platov South-Russian State Polytechnic University (NPI), 346428, Rostov region, Novocherkassk, Prosveshcheniya, 132, Russia \\ ${ }^{2}$ Don State Agrarian University, 346493, Rostov region, Persianovski set., Octyabrski district, Russia
}

\begin{abstract}
The tasks of thermal power plants (TPPs)modernization are to improve technical and environmental indicators, reduce the cost of energy, and take into account the requirements of international and Russian legislation. At the initial stage of modernization design, coordination of TPP indicators with specialists of various profiles and development of a general concept and structure of the station is necessary. In the traditional technical standards of the Russian Federation there are no documents regulating this process. To date, developed and adopted as national standards in a number of countries, including Russia, the IDEF methodology and family of standards, covering all stages and design aspects. This article discusses some aspects of the IDEF0 standard application at the initial stage of designing the TPPs modernization.
\end{abstract}

\section{Introduction}

Any technical objects in the process of operation become obsolete physically and mentally. To bring the operated technical facilities in line with modern technical, environmental, legal, social requirements, modernization or reconstruction is required. The purpose of TPPs modernization is to increase work efficiency according to a set of diverse criteria. The tasks of TPPs modernization are to improve technical and environmental indicators, reduce energy production cost, take into account the requirements of international and Russian legislation, increase reliability and reduce the risk of accidents, to improve the social relations in the station located region. Modernization of existing thermal power plants includes a number of stages: determination and analysis of thermal power plant problems, setting goals and tasks of modernization, studying the market of specialized technologies and equipment, preliminary preparation of alternative modernization projects, choosing a priority project [1], pre-project preparation of documentation and object of modernization, design (often understood as exclusively technical), project implementation, testing and commissioning, operation of the upgraded TPP.

Thermal power plants, especially solid fuel ones, have a great negative impact on the environment. As the result of fuel combustion, ash and slag materials are generated and accumulated, harmful oxides and excess steam are released into the atmosphere, soil and water bodies are polluted by heavy metals, and thermal pollution occurs. One of the ways to solve these problems is the transformation of thermal power plant into an energy technology complex (ETC) in the process of modernization. The task of the TPP functioning is the production of energy, electric and, possibly, thermal. The task of the ETC functioning is waste-free energy production; other (material) marketable products are produced from the energy cycle waste. In addition to a power plant as a producer of electric and thermal energy (heat-energy zone), an ETC based on TPPs can include up to 5 additional zones in various configurations (industrial separation, industrial utilization, analytical, service, transport and logistics) [2].

Design and operation of thermal power plants in Russia are standardized by a variety of regulatory and technical documents [3-8, etc.]. However, a number of aspects of the TPP life cycle, which must be agreed upon before the start of the technical design, are not covered by these documents. In some cases, these aspects should be agreed with environmentalists, lawyers, economists and other specialists who do not have technical education and do not have the skills to work with technical documents, drawn up, for example, according to a unified system of design documentation (USDD).

At the end of the 20th century, a methodology and a family of IDEF standards were developed, covering all stages and design aspects [9-12]. IDEF standards are accepted as national standards in a number of countries. The IDEF0 methodology is also adopted in Russia [1315]. The IDEF methodology has an intuitive graphic language, which makes it possible to use it as a means of interprofessional communication, including when designing the modernization of thermal power plants in ETC [16]. 


\section{Design standards for thermal power plants}

Today, two groups of design standards can be distinguished: traditional technical standards (in Russia these are state standards of the Russian Federation) and standards based on the functional modeling methodology (IDEF).

Design of thermal power plants in Russia is carried out in accordance with national technical standards [3-8]. Separate documents, for example, $[17,18]$, regulate the procedure for TPPs technical and economic indicators calculating. But many aspects that need to be coordinated with relevant specialists and taken into account during design cannot be fully implemented and described by these means, namely:

- legislative conditions governing the construction and operation of TPPs;

- organizational relationships of TPPs with suppliers of fuel, equipment, consumables, repair organizations, electric grid companies;

- the impact of TPPs on the environment, the amount of waste produced and the possibility of their disposal;

- relationship with the social sphere, the number of jobs created, the need for various qualifications workers, the ability to train the required specialists in the station located region;

- regional conditions, including climatic and infrastructural;

- the need for electrical and thermal energy, including daily, weekly, seasonal, annual load fluctuations;

- risks of various nature, etc.

From the position of technical documentation, TPP is considered in isolation and only from a technical and technological point of view. But to ensure the successful functioning of the station should be considered as a complex system in collaboration with the external environment [19]. To take into account all aspects of the TPP life cycle, technical specialists will have to contact lawyers, economists, ecologists, sociologists, systems analysts, investors who speak other professional languages, which leads to the need to develop means of interprofessional communication.

Requirements for the design documentation (graphic and text documents that fully and unambiguously determine the composition and structure of the product and contain all the necessary data for its development, manufacture, control, operation, repair and disposal), similar to the USDD RF, exist in different countries, have its features and the trend towards world uniformity [20-24]. These requirements, legally documented in national standards, continue to apply along with adopted national standards based on the IDEF methodology (United Kingdom, [25]). The current system of normative and technical documentation of the Russian Federation and the IDEF0 standard do not contradict each other and are not alternative, since they have different fields of application in the process of design and operation of TPPs. In particular, the use of the IDEF0 standard is advisable at the initial stage of design.
The IDEF0 standard, and subsequently other IDEF family standards that do not currently have an interpretation in USDD RF, should mutually complement technical standards and regulations. This will speed up the design process and increase the efficiency of TPPs operation.

\section{Methodology and family of IDEF standards}

\subsection{IDEF methodology overview}

In the 70 s of the XX century, new approaches began to be developed to describe the structure and functions of complex systems, taking into account both the needs of social communication in the projects design and the opportunities provided by modeling and using computer software [26, 27]. One of such approaches was the development of a methodology and family of IDEF (Integrated DEFinition) standards, including 15 standards, covering all stages and design aspects [9-12] (Table 1).

Table 1. Classification of IDEF standards.

\begin{tabular}{|c|c|}
\hline Designation & Name \\
\hline IDEF & Integration Definition Metodology \\
\hline IDEF0 & Function Modeling \\
\hline IDEF1 & Information Modeling \\
\hline IDEF2 & Simulation Model Design \\
\hline IDEF3 & Process Description Capture \\
\hline IDEF4 & Object-Oriented Design \\
\hline IDEF5 & Ontology Description Capture \\
\hline IDEF6 & Design Rationale Capture \\
\hline IDEF7 & Information System Auditing \\
\hline IDEF8 & User Interface Modeling \\
\hline IDEF9 & Business Constraint Discovery method \\
\hline IDEF10 & Implementation Architecture Modeling \\
\hline IDEF11 & Information Artifact Modeling \\
\hline IDEF12 & Organization Modeling \\
\hline IDEF13 & Three Schema Mapping Design \\
\hline IDEF14 & Network Design \\
\hline
\end{tabular}




\subsection{Functional modeling in the IDEF0 standard}

Modern functional modeling is defined by the National Institute of Standards and Technology, USA, IDEF0 standard [9], which directly describes the methodology of functional modeling and graphical notation for representing the generated models. This technology is taken as the basis for the development of national standards in a number of countries. So in the UK in 1993, a similar SSADM (Structured Systems Analysis and Design Method) methodology was adopted as a national standard for the information systems development [25]. At the end of the 20th century, the Russian version of the IDEF0 standard was presented [13], later the State Standard of Russia developed, adopted and put into operation functional modeling standards [14-15] recommended for use in government agencies in order to support, in particular, the certification procedure for production activities for compliance with international standards ISO 9000 (9001) for the creation of quality management systems. In recent years, the need to harmonize Russian standards with foreign standards, both in terms of product requirements and documentation, is relevant for organizations that have foreign partners. Thus, the use of the IDEF0 standard is a normatively justified design stage in the Russian Federation.

The IDEF0 standard is the first in the IIDEF standards line. It is based on the concept of system units and the relationships between them. The IDEF0 methodology is based on an approach called SADT (Structured Analysis \& Design Technique). The basis of this approach and IDEF0 methodology is the graphic language for the description (modeling) of systems. Each functional block (object, process) within the framework of a single system under consideration must have its own unique identification number (Fig. 1, A0). A block has three inputs: on the left is an input stream, material, informational or other, subjected to processing and transformation in a given functional block, on top is a control action that affects the transformation algorithm of a functional block, on the bottom is a mechanism, means that allow the block to perform functional tasks, convert input stream to output. For the block, the output on the right is the result of the conversion, the output stream. According to the recommendations of [13], an informational output stream at the bottom can be provided - a challenge, feedback. When constructing and analyzing IDEF0 models, the focus is on the relationships between the blocks, rather than their (temporal) sequence.

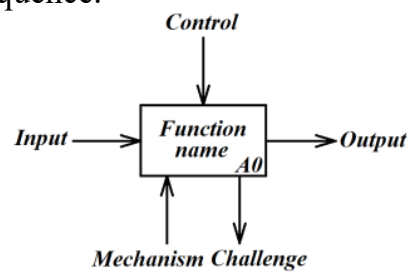

Fig. 1. Functional blok.

The IDEF0 language is standardized in terms of syntax and semantics. Therefore, functional models are clearly defined, well-structured, visual, modifiable and easy to use, and can have any depth of detail defined by the developer. IDEF0 models are three-dimensional, since any two-dimensional IDEF0 diagram can be supplemented by child functions represented on different layers or levels of the model. There are no restrictions on the number of child functional layers in the IDEF0 model. The standard provides for the possibility of developing models of two object states: AS-IS and TOBE. Changes in the object during the transition from one state to another, new blocks and connections are distinguish visually (Fig. 2-7), in contrast to the schemes made in accordance with the USDD RF (Fig. 8, 9). The IDEF0 standard allows you to simulate both functional (Fig. 2-7) and structural (Fig. 10-13) circuits without overloading the created model with data that is redundant for specific purposes.

\section{Energy facilities modeling using the IDEF0 standard}

\subsection{An example of IDEF0 model constructing and an analysis of TPP ash and slag removal system simulation results}

During the modernization of TPP in the ETC, the focus is on the ash and slag materials disposal. In [1], using the Saaty's Analytic Hierarchy Process, it was shown that this strategy is a priority in a wide range of diverse indicators values compared to strategies of other energy cycle wastes disposal.

The two-level model of ash and slag removal AS-ISprocess at TPP is presented in fig. 2-3. The four-level model of ash and slag removal and disposal TO-BEprocess at ETC is presented in fig. 4-7. For comparison, in fig. 8-9 shows the flow chart of ash hydrotransportation at TPP / ETC with dry ash collectors, made in accordance with the technical standards of the Russian Federation.

In fig. 8, we can trace the movement of slag and ash, starting from the slag bath of the boiler and ash collectors and ending with the ash and slag dump. A part of the TPP water path related to the ash and slag removal system is shown. The main elements of the equipment are shown, but their relative position is rather arbitrary. The arrows indicate the movement of water, air, ash, slag and ash-and-slag pulp, the medium specific form becomes apparent from the context of the scheme. The dotted line marks the zone related to the main building of the TPP. Instrumentation locations are indicated on special diagrams. The requirements for staff, the procedure for site maintenance, and routine maintenance are reflected in job descriptions. Laws, state standards and technical regulations related to the design and operation of this workshop were taken into account at the initial stage of design. Changes in the legislation, in particular, in the field of coal waste management, may lead to the need of change this scheme. But at the same time, the legislative, environmental, economic, staff and social aspects of the TPP design and operation, affecting 
the work order and composition of technical documentation, do not themselves relate to technical documentation and are not combined in single document.

According to fig. 2-7, all the components of the input stream «Control» (Laws, State standards, Technical regulations, Standards) and the components of the input stream «Mechanism» (Devices, Staff) are applied to all decomposition blocks without further elaboration. They form the so-called «Ttunnels», therefore, they are shown only in context diagrams. «Equipment», as a compo-nent of the «Mechanism» input stream, also applies to all blocks, but with the details disclosed in the corresponding diagrams.

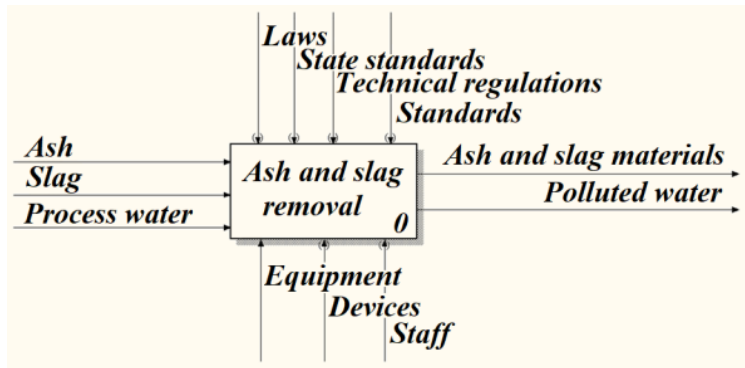

Fig. 2 Context diagram of the AS-IS-process ash-and-slag removal at TPP.

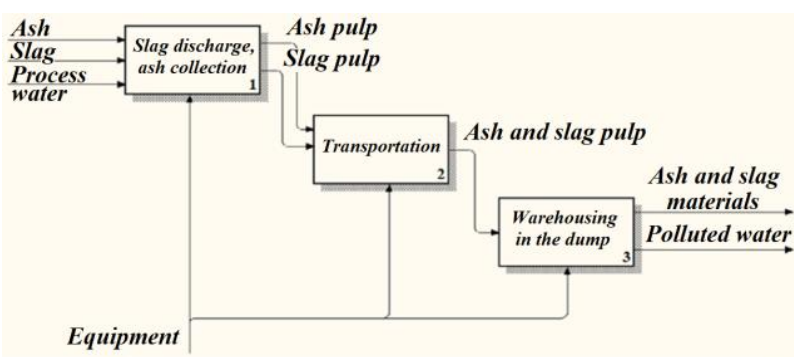

Fig. 3 Decomposition of the AS-IS-process context diagram of the ash-and-slag removal at TPP.

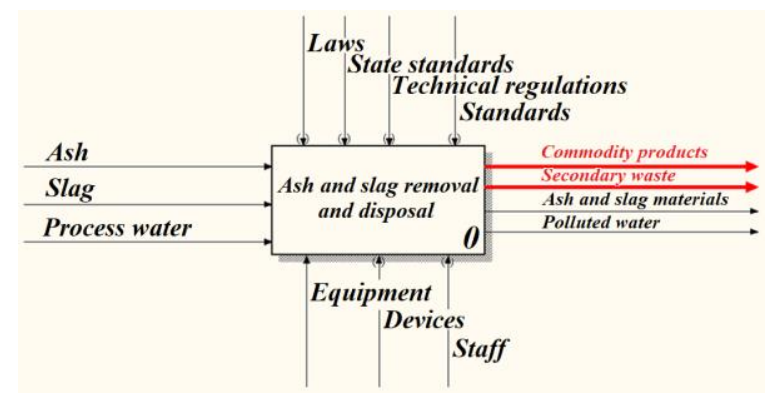

Fig. 4 Context diagram of the TO-BE-process ash-and-slag removal and disposal at ETC

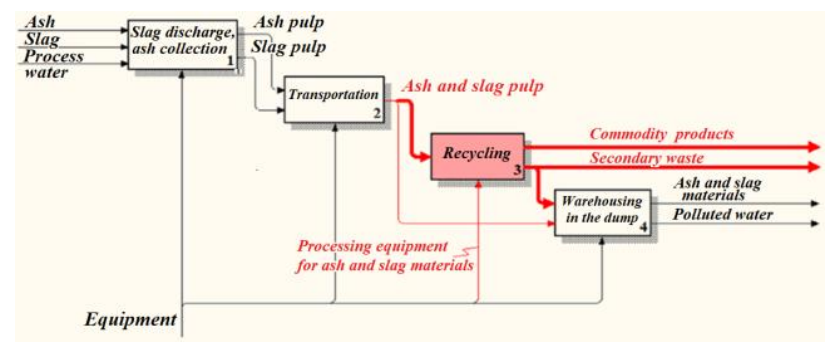

Fig. 5 Context diagram of the TO-BE-process ash-and-slag removal and disposal at ETC

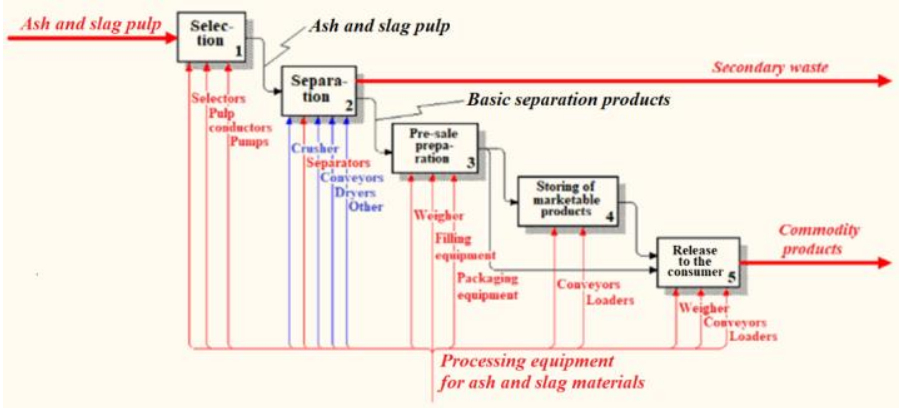

Fig. 6 Decomposition of the TO-BE-process «Recycling» stage of the ash-and-slag removal and disposal at ETC.



Fig. 7 Decomposition of the TO-BE-process «Separation» stage of the ash-and-slag removal and disposal at ETC.

In fig. 2 in the format of a context diagram, material flows are shown that in the «Ash and slag removal» function block are transformed, as well as the conditions and means of the transforming process. Quantitative characteristics can be indicated, for example, the volume of water con-sumed or the mass of the resulting ash and slag materials over a fixed period of time. If it is necessary to coordinate the positions of the diagram with lawyers, specific regulatory documents of the international, federal or regional levels, for example, dates of adoption and validity of licenses for land use and water use, can be indicated. In fig. 3 the decomposition of the context diagram is shown, the main stages of the ash and slag removal process are highlighted, and the phased conversion of input streams to output is shown. When considering this diagram, it is possible to agree on the complexity of the stages (introducing the Staff characteristics on the field of the diagram, indicating the labor costs, qualifications, and tolerance levels by stages). If necessary, the diagrams (fig. 2, 3) may indicate the marking and tech-nical characteristics of the equipment, in particular, the year of commissioning. This will make it possible to visualize the least reliable sections of the technological scheme that require priority equipment replacement. On technical informativeness the IDEF0 diagrams of the lower decomposition level correspond to the schemes of technical standards (Fig. 8). At the same time, the package of IDEF0 diagrams allows you to structure the process of ash and slag removal and present related information of legal, financial, social content, the coordination of which with relevant specialists is necessary when designing and operating the ash and slag removal system. 
In fig. 4-7 shows the TO-BE process of ash and slag removal and disposal at the ETC with the introduction of the ash and slag processing section, in fig. $9-$ a modernized ash and slag removal scheme, made in accordance with state technical standards RF.

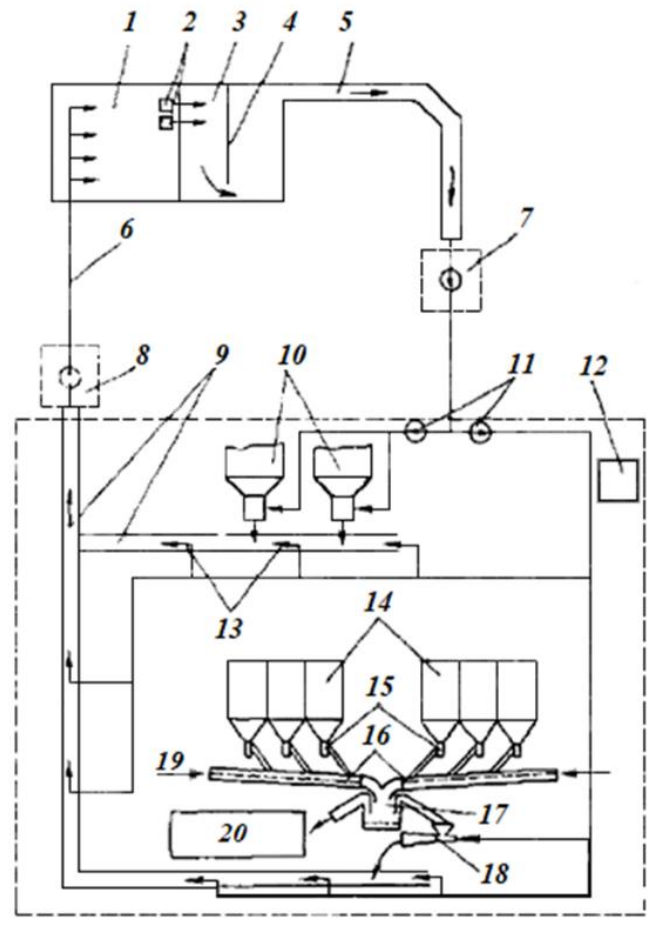

Fig. 8 Scheme of hydraulic ash removal at TPPs with dry ash collectors: 1 - ash and slag dump, 2 - mine wells, 3 - clarified water pool, 4 - separation dam, 5 - open channel, 6 - pulp line, 7 - pumps, 8 - pressure pumps, 9 - gravity channels, 10 - slag bath of the boiler, 11 - flushing pumps, 12 - installation for periodic cleaning of pipelines from carbonate deposits, 13 incentive nozzles, 14 - ash collectors, 15 - pneumatic sluice gates or flashers, 16 - air chute, 17 - the end pneumatic layer shutter-switch, 18 - the mixing device for reception of an ash pulp, 19 - compressed air, 20 - dry ash.

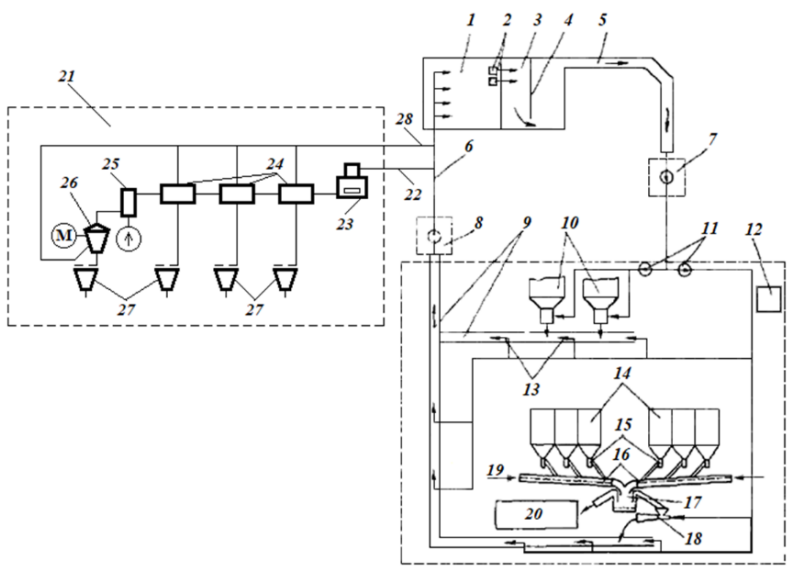

Fig. 9 Scheme of hydraulic ash removal at TPPs with dry ash collectors and the introduced section for processing of ash and slag materials: 1-20 - similarly to Fig. 7, 21 - section for processing ash and slag materials, 22 - selection of ash and slag for processing, 23 - crusher, 24 - devices for the isolation of morphological and chemical components, 25 - dryer, 26 mechanical separator, 27 - bunkers of finished products, 28 disposal secondary waste.
The diagram (fig. 9) shows the ash and slag processing section general structure and the specific place of this section introduction. The scheme format does not provide for the indication of measuring instruments on it, in particular, for monitoring the content of radionuclides, the flow of water, air and electricity. The marking and parameters of the input equipment are indicated in the specification or in the text part of the project.

According to fig. 4-7, in the TO-BE process, as compared to the AS-IS process, new components of the output stream are added - «Commodity products» and «Secondary waste». These changes will affect the entire technological cycle: the required amount of process water will change, new laws and regulations, measuring instruments and equipment will be required, the requirements for staff training will change.

The most serious changes will affect the «Equipment»: new devices will be required, such as Separators, Crushers, Dryers, Scales, etc. Moreover, the Separators group combines devices that are different in purpose and principle of action: for the separation of carbon, magnetic separation of iron, mechanical separation by size, etc. To draw attention to this aspect, this equipment group is highlighted. It is planned to store secondary separation waste in the dump, which will affect the composition and properties of the material product located in the dump. The «Slag removal, ash collection» stage has not changed, the changes in the «Transportation» and «Warehousing in the dump» stages are insignificant, therefore, their decomposition is not shown on the TO-BE diagrams. Upon completion of the «Transportation» stage, ash-and-slag pulp is transferred either to «Warehousing in the dump» or to «Processing» - a new stage, which includes, in particular, «Separation», «Pre-sale preparation» and «Release to the consumer» of Commodity products based on ash and slag. Processing of ash and slag materials can be carried out both within the framework of a single energy technological complex on the basis of a coal TPP, and delegated to special structures independent of TPP. Modernization of the TPP ash and slag removal system, presented in Fig. 4-7, the most simple to implement, since it does not connect with the process of ash and slag formation in the TPP boiler and with the subsequent removal of ash and slag from the boiler. But at the same time, it does not take into account some of the features and possibilities provided by the TPP technological cycle, such as liquid slag separation during liquid slag removal, use of flue and mill gases for drying, use of contaminated wet gases which formed in the processing of ash and slag materials in the TPP technological cycle, etc.

\subsection{The modernization project of TPP into ETC in the IDEF0 standard}

In fig. 10 shows the AS-IS-structural diagram of TPP in the IDEF0 standard, in fig. 11 - decomposition of the context diagram. In fig. 12,13 - the context TO-BEstructural diagram of ETC based on TPP and its 
decomposition, respectively. Internal flows that remain unchanged are not shown. In TO-BE diagrams, the color indicates the addition of new or changing process units and flows.



Fig. 10 The TPP structural scheme in the AS-IS IDEF0 context diagram format.



Fig. 11 Decomposition of the context AS-IS diagram IDEF0 of the TPP structural scheme.

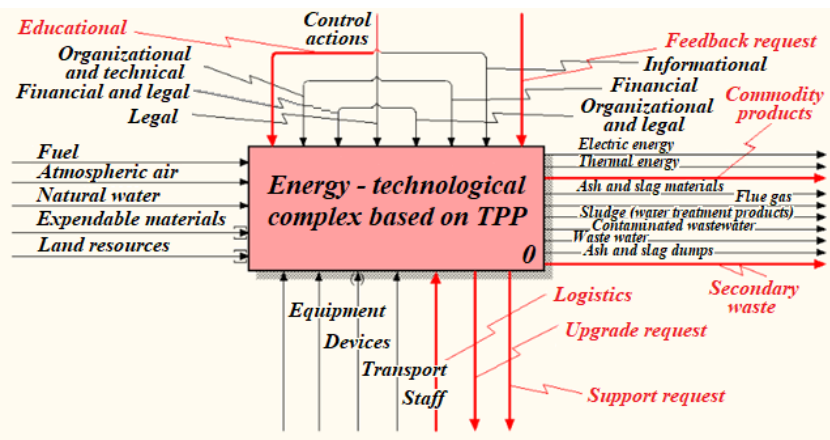

Fig. 12 The ETC structural scheme in the TO-BE IDEF0 context diagram format.

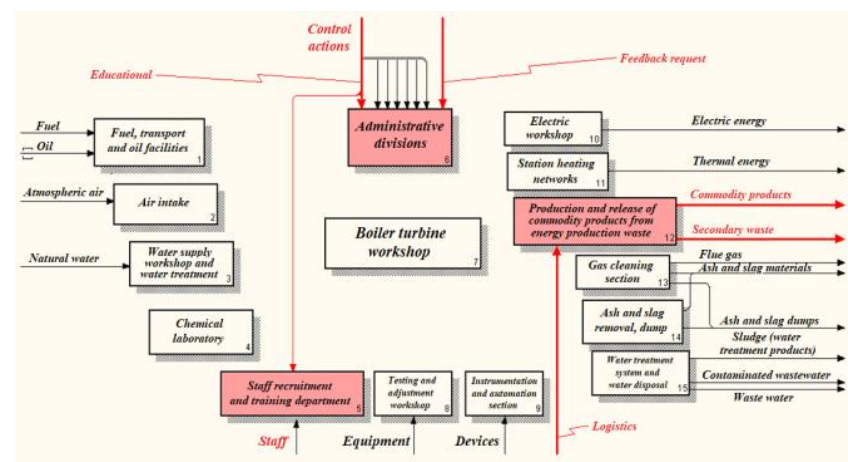

Fig. 13 Decomposition of the context TO-BE diagram IDEF0 of the ETC structural scheme.
The TO-BE context diagram shows that, compared to TPP, new material products are added for the ETC Commodity products (from waste from the energy cycle) and Secondary waste. To fulfill the function of commodity production, conditions are necessary - the availability of logistics, support for the modernization of TPP and its transformation into an ETC (material, technical, financial, information and legal, organizational). A request for support is formed during the modernization of TPP.

Successful modernization requires changes in legislation, in state standards and norms, in the system of benefits, subsidies and fines, in organizational structures at the state level that oversee the energy facilities modernization. To increase the efficiency and effectiveness of these changes, feed-back of the information-legal environment and the internal material and financial environment of ETC is required, which is reflected in the introduction of the corresponding impact into the TO-BE diagrams. Also added a new control action - Educational. The ETC development, implementation and operation increase the staff qualification requirements.

The ETC functioning financial success depends directly on its adaptability: to the requirements of the consumer market, to the emerging market for innovative technology and equipment, to changing operating conditions.

\subsection{Specifics of using the IDEFO standard for energy facilities}

Designing using IDEF standards in comparison with our traditional design technologies, taking into account the Russian Federation state technical standards, has its own capabilities, features, advantages and disadvantages, and the scope of primary applicability (Table 2).

Table 2. Specifics of using the IDEF0 standard for energy facilities.

\begin{tabular}{|c|c|c|}
\hline $\begin{array}{l}\text { Charact } \\
\text { eristics }\end{array}$ & $\begin{array}{l}\text { State standards of the } \\
\text { Russian Federation }\end{array}$ & IDEF0 standard \\
\hline 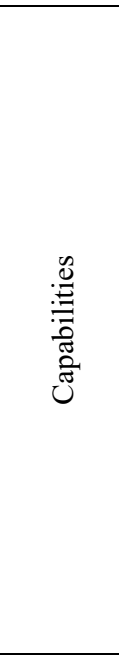 & $\begin{array}{l}\text { Detailed technical } \\
\text { project } \\
\text { The specification, } \\
\text { drawings, conditional } \\
\text { graphic designations } \\
\text { (CGD) are standardized } \\
\text { The feasibility study is } \\
\text { performed separately } \\
\text { Work schedules are } \\
\text { developed separately }\end{array}$ & $\begin{array}{l}\text { A single project includes } \\
\text { technical, financial, } \\
\text { legal, organizational } \\
\text { information } \\
\text { A small amount of CGD } \\
\text { - named blocks and } \\
\text { arrows } \\
\text { The ability to not display } \\
\text { non-essential items } \\
\text { Unlimited } \\
\text { decomposition depth } \\
\text { The ability to display the } \\
\text { sequence, duration and } \\
\text { cost of blocks } \\
\text { The ability to display } \\
\text { various points of view } \\
\text { on the project, experts } \\
\text { data }\end{array}$ \\
\hline 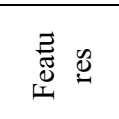 & $\begin{array}{l}\text { Strict guidelines for the } \\
\text { drawings and text } \\
\text { documents design }\end{array}$ & $\begin{array}{l}\text { Design } \\
\text { recommendations }\end{array}$ \\
\hline
\end{tabular}


Continuation of the table 2 .

\begin{tabular}{|c|c|c|c|}
\hline \multicolumn{2}{|c|}{  } & $\begin{array}{l}\text { An image of technical } \\
\text { objects with a } \\
\text { completeness that } \\
\text { allows them to be } \\
\text { implemented materially } \\
\text { (to build, carve, etc.) } \\
\text { Unification and } \\
\text { standardization of CGD } \\
\text { establishes a one-to-one } \\
\text { correspondence } \\
\text { between circuit } \\
\text { elements and equipment } \\
\text { State standards } \\
\text { fundamentals is taught } \\
\text { in educational } \\
\text { institutions }\end{array}$ & $\begin{array}{l}\text { Coherence with } \\
\text { international standards } \\
\text { Simplified CGD } \\
\text { Visibility and clarity for } \\
\text { specialists in various } \\
\text { fields of activity }\end{array}$ \\
\hline \multicolumn{2}{|c|}{ 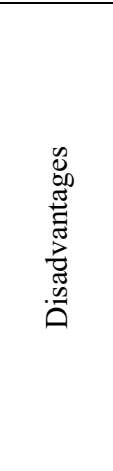 } & $\begin{array}{l}\text { This is clear only to } \\
\text { technical specialists on } \\
\text { the project profile } \\
\text { Contain redundant } \\
\text { technical information } \\
\text { for the initial design } \\
\text { phase } \\
\text { Do not contain non- } \\
\text { technical information } \\
\text { required at the initial } \\
\text { design stage and during } \\
\text { the modernization of the } \\
\text { facility }\end{array}$ & $\begin{array}{l}\text { Not applicable for the } \\
\text { technical implementation } \\
\text { of the project } \\
\text { (construction, } \\
\text { manufacture of the } \\
\text { object) } \\
\text { Lack knowledge of } \\
\text { various profiles } \\
\text { specialists about the } \\
\text { capabilities of standard }\end{array}$ \\
\hline \multirow[t]{2}{*}{ 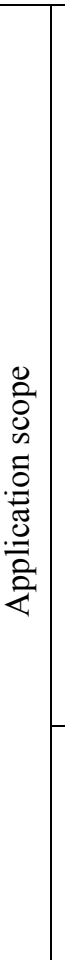 } & 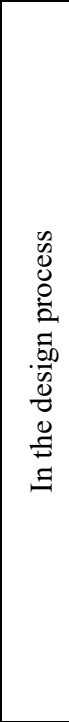 & $\begin{array}{l}\text { At the stage of project } \\
\text { implementation } \\
\text { When developing } \\
\text { technical solutions } \\
\text { When calculating the } \\
\text { criteria and indicators of } \\
\text { technical and economic } \\
\text { efficiency } \\
\text { When choosing } \\
\text { equipment } \\
\text { When developing } \\
\text { technical documentation } \\
\text { for the implementation } \\
\text { of the facility }\end{array}$ & $\begin{array}{l}\text { At the stage of } \\
\text { development and } \\
\text { approval of the project } \\
\text { When setting goals and } \\
\text { design tasks } \\
\text { In the formation } \\
\text { (selection) of } \\
\text { performance evaluation } \\
\text { criteria } \\
\text { When forming the } \\
\text { technological and } \\
\text { organizational structure } \\
\text { of an object } \\
\text { When coordinating the } \\
\text { project with non- } \\
\text { technical specialists } \\
\text { (lawyers, ecologists, } \\
\text { economists, etc.) } \\
\text { When developing } \\
\text { documentation }\end{array}$ \\
\hline & 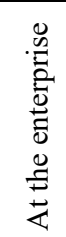 & $\begin{array}{l}\text { Chief engineer and } \\
\text { organizational } \\
\text { structures under his } \\
\text { control at the enterprise }\end{array}$ & $\begin{array}{l}\text { Director of the enterprise } \\
\text { Legal service } \\
\text { Financial service } \\
\text { Staff service, etc. }\end{array}$ \\
\hline
\end{tabular}

\subsection{IDEF0 standard application methodology in the energy facilities design}

Designing using the IDEF0 standard (as well as other standards of the IDEF family) is a methodological tool, an approach to the design process. This technique allows you to optimize the design process, but not its result. The design process in the broad sense is not only technical design, but also related issues inseparable from it. Process optimization is the reduction of time for coordination, taking into account various aspects and points of view, the ability to choose the best option based on a set of criteria. It does not explicitly include technical and economic calculations, does not affect the choice of specific technological schemes and brands of equipment (these calculations and decisions remain with specialists - engineers and economists), and does not allow us to say that the efficiency of the system is increased with the use of this technique. But according to the documents [13-15], the use of the IDEF0 standard is a normatively justified design stage in the Russian Federation, as legitimate as the application of state technical standards.

The methodology for applying the IDEF0 standard in the design of energy facilities modernization includes the steps of:

- audit: analysis of design documentation, technical passport and the actual condition of the facility;

- formulation of the goals and tasks of modernization;

- construction and analysis of AS-IS diagrams in the IDEF0 standard;

- development of alternative modernization projects;

- selection and justification of a priority project (for example, using the Saaty method);

- construction and analysis of TO-BE diagrams in the IDEF0 standard;

- development of design documentation for the project implementation.

\section{Conclusions}

On the example of a functional diagram of the TPP ash and slag removal system modernization with the introduction of ash and slag processing workshop and a TPP structural diagram, the individual stages of the methodology for developing an energy facility modernization project to by constructing AS-IS and TOBE models in the IDEF0 standard are shown. The use of functional modeling in the IDEF0 standard is an effective and visual tool for displaying and analyzing the structure and functions of energy production facilities, process business planning and generation of modernization projects for these facilities.

The current system of normative and technical documentation of the Russian Federation and the IDEF0 standard are not alternative, since they have different fields of application. IDEF standards, and in particular, IDEF0, and technical standards should complement each other, which will speed up the design process and increase the efficiency of TPP operation. Models of the IDEF0 standard cannot replace traditional detailed technical plans and schemes, but are convenient and effective at the initial stage of design (planning) and can become the basis for the further development of detailed schemes in accordance with state technical and design standards. 


\section{References}

1. Fedorova, N. The features of Saaty analytic hierarchy process application for the choice of modernization strategy of energy objects / Energy System Research 2019 E3S Web of Conferences 114,01001 (2019). URL: https:/www.e3sconferences.org/articles/e3sconf/pdf/2019/40/ e3sconf_esr2019_01001.pdf

2. Fedorova, N. Systemic aspects of the energy complex based on coal TPP / Energy System Research 2019 E3S Web of Conferences 114, 06001 (2019). URL: https://www.e3sconferences.org/articles /e3sconf/pdf/2019/40/e3sconf_esr2019_06001.pdf

3. Code of Regulations RF 90.13330.2012 Thermal power plants. Updated version of Building Regulations II-58-75 (with Amendment No. 1). The date of introduction is 2013-01-01.

4. State standard RF 2.001-2013 Unified system of design documentation (USDD). General provisions (with Amendment). The date of introduction is 2014-06-01.

5. State standard RF 2.701-2008 Unified system of design documentation (USDD). Scheme. Kinds and types. General requirements for implementation (with Amendment). The date of introduction is 2009-07-01.

6. State standard RF 21.403-80 System of design documentation for construction (SDDC). Conditional graphic designations in schemes. Power equipment. The date of introduction is 1981-07-01.

7. Sternman, L.S. Thermal and nuclear power plants. Textbook for high schools / L.S. Sternman, V.M. Lavygin, S.G. Tishin // M : Publishing House of MPEI, 2000. - $408 \mathrm{p}$.

8. The set of rules for the thermal power plants design // Moscow, Russian joint-stock company «Unified energy systems of Russia», 2007. - 175 p.

9. NIST, FIPS. Publication 183: Integration Definition of Function Modeling (IDEF0) // National Institute of Standards and Technology. - 1993. - T. 128. URL: http://www.idef.com

10. Ross, D. T. Architect's Manual, ICAM Definition Method IDEF0 / D.T. Ross et al. // Computer Aided Manufacturing International, 1980.

11. Marca, D.A. SADT: structured analysis and design technique / D.A. Marca, C.L. McGowan // McGrawHill Book Co., Inc.: New York, 1988. - 392 p.

12. Bravoco, R.R. Requirement definition architecture an overview / R.R. Bravoco, S.B. Yadav // Computers in Industry, 1985. - T. 6. - №. 4. - P. 237-251.

URL: https://www.sciencedirect.com/science/article/pii/01 66361585900466

13. Working paper Methodology of functional modeling IDEF0 // M.: State standard of Russia, 2000. - 75 p. URL: https://nsu.ru/smk/files/idef.pdf
14. R 50.1.028-2001 Information technology support product life cycle. Functional Modeling Methodology // M.: State standard of Russia. Introduction date 2002-07-01.

15. R 50.1.031-2001 Information technology support product life cycle. Terminological dictionary. Part 1. The stages of the product life cycle // M.: State standard of Russia. - Introduction date 2002-07-01.

16. Fedorova, N.V. Some aspects of functional modeling in the IDEF0 standard as the initial stage of TPPs design / N.V. Fedorova and others // DTS2019 AIP Conference Proceedings 2188, 050010 (2019).

URL: https://aip.scitation.org/doi/pdf/10.1063/1.5138437? class $=$ pdf

17. A typical algorithm for calculating the technical and economic indicators of powerful heating centers. Part 1. Organizational and technological essence of the calculations/ Leningrad, 1981.

18. Working paper 153-34.1-09.321-2002. Methodology for rapid assessment of the economic efficiency of energy-saving measures at thermal power plants. Introduction date 2003-03-01.

19. Fedorova, N.V. Functional modeling in the IDEF0 standard as a tool for describing the processes of TPPs operation and upgrading / N.V. Fedorova, D.A. Shaforost, V.N. Baltyan, A.M. Kolomiytseva // Proceedings of universities. North Caucasus region. Series: Engineering. - 2018. - №. 3 (199). - P. 6169.

20. ISO 128 Technical drawings - Indication of dimensions and tolerances.

21. ISO 7083 Symbols for geometrical tolerancing Proportions and dimensions.

22. ISO 13715 Technical drawings - Edges of undefined shape - Vocabulary and indications.

23. ISO 15786 Simplified representation and dimensioning of holes.

24. ISO 16792:2015 Technical product documentation Digital product definition data practices.

25. Pokhilko, A. F. Modeling of processes and data using CASE-technologies: a tutorial / A.F. Pohilko, I.V. Gorbachev, S.V. Ryabov // Ulyanovsk: UISTU, 2014. - 163 p. 163 URL: http://venec.ulstu.ru/lib/disk/2014/179.pdf

26. Venikov, V. A. Fundamentals of the theory of similarity and modeling: Terminology / V.A. Venikov // M.: Science, 1973. - T. 88.

27. Ramus - cross-platform system for modeling and analysis of business processes / Official Russianlanguage website of the project Ramus! URL: http://ramussoftware.com/ 